\title{
Review Article \\ PPAR Action in Human Placental Development and Pregnancy and Its Complications
}

\author{
Fritz Wieser, Leslie Waite, Christophe Depoix, and Robert N. Taylor \\ Department of Gynecology and Obstetrics, Emory University School of Medicine, Atlanta, GA 30322, USA
}

Correspondence should be addressed to Robert N. Taylor, robert.n.taylor@emory.edu

Received 2 September 2007; Accepted 13 November 2007

Recommended by P. Froment

During pregnancy crucial anatomic, physiologic, and metabolic changes challenge the mother and the fetus. The placenta is a remarkable organ that allows the mother and the fetus to adapt to the new metabolic, immunologic, and angiogenic environment imposed by gestation. One of the physiologic systems that appears to have evolved to sustain this metabolic regulation is mediated by peroxisome proliferator-activated receptors (PPARs). In clinical pregnancy-specific disorders, including preeclampsia, gestational diabetes, and intrauterine growth restriction, aberrant regulation of components of the PPAR system parallels dysregulation of metabolism, inflammation and angiogenesis. This review summarizes current knowledge on the role of PPARs in regulating human trophoblast invasion, early placental development, and also in the physiology of clinical pregnancy and its complications. As increasingly indicated in the literature, pregnancy disorders, such as preeclampsia and gestational diabetes, represent potential targets for treatment with PPAR ligands. With the advent of more specific PPAR agonists that exhibit efficacy in ameliorating metabolic, inflammatory, and angiogenic disturbances, further studies of their application in pregnancy-related diseases are warranted.

Copyright (C) 2008 Fritz Wieser et al. This is an open access article distributed under the Creative Commons Attribution License, which permits unrestricted use, distribution, and reproduction in any medium, provided the original work is properly cited.

\section{INTRODUCTION}

Peroxisome proliferator-activated receptors (PPARs) are major regulators of lipid and glucose metabolism, inflammation, and angiogenesis [1-6] that allow adaptation of the mother to the nutritional and perfusion requirements of the fetus $[3,7,8]$. PPARs, members of the nuclear hormone receptor superfamily, are ligand-activated transcription factors. The PPAR amino acid sequence can be divided into five modular domains: A/B, C, D, E, and F. Domain E is the ligand binding domain (LBD) and contains a liganddependent transcriptional activation function (AF-2). Domain $\mathrm{C}$ is the DNA binding domain, formed of two typical zinc fingers. PPARs activate DNA direct repeat response elements by binding as heterodimers with retinoic acid receptor (RXR) partners [9]. There are three PPAR isotypes, $\operatorname{PPAR} \alpha, \operatorname{PPAR} \gamma$, and $\operatorname{PPAR} \beta / \delta$, that are highly conserved across species, with mouse, rat, and human sequences sharing $>80 \%$ amino acid homology $[6,10]$. The conserved expression of different PPAR and RXR isotypes in both rat and human placentas [11] suggests that these receptors play functional roles in placental lipid transfer and homeosta- sis. PPAR $\alpha$ has a wide distribution and is prominent in tissues with high metabolic rates such as liver, heart, skeletal muscle, and kidney and in steroidogenic organs such as the adrenals [12]. PPAR $\gamma$ has three isoforms (PPAR $\gamma 1, \gamma 2$, and $\gamma^{3}$ ) and is expressed in brown and white adipose tissue, large intestine, to a lesser extent in immune cells (monocytes, macrophages, Peyer's patches of the digestive tract), the mucosa of colon and cecum, and placental trophoblasts [13-16]. $\operatorname{PPAR} \beta / \delta$ is distributed in all tissues tested with particularly high expression in placenta and large intestine $[8,17,18]$. $\operatorname{PPAR} \alpha$ and PPAR $\gamma$ are involved in adipocyte differentiation, lipid metabolism, insulin action, and in the regulation of inflammatory responses $[1,5,16]$, particularly involving the macrophage [19]. PPAR $\beta / \delta$ is known to be involved in lipid metabolism and inflammation, as well as keratinocyte differentiation and wound healing $[5,20,21]$.

The PPAR system is intimately involved in cardiovascular disease, obesity, as well as pregnancy-specific diseases $[6,22]$. Over the past decade studies have shown that all three PPAR isotypes are expressed in human placental trophoblast cells [11] and that they are involved in the regulation of pregnancy physiology and its clinical complications. Physiological and 
TABLE 1: Effects of physiological and pathophysiological conditions on PPAR.

\begin{tabular}{|c|c|c|c|}
\hline \multicolumn{4}{|c|}{ Influence on PPAR action } \\
\hline Conditions & PPAR-action & Model & Reference \\
\hline Diabetes & Increases PPAR $\gamma$ in skeletal muscle & Murine & Park et al. [22] \\
\hline \multirow{2}{*}{ Age } & Increases PPAR $\gamma$ in subcutaneous fat in older man & Human & Imbeault et al. [23] \\
\hline & Decreases PPAR $\alpha$ in heart & Murine & Iemitsu et al. [24] \\
\hline Hypertension & Increases PPAR $\alpha$ and $\gamma$ in aorta and mesenteric arteries & Murine & Diep and Schiffrin [25] \\
\hline \multirow{4}{*}{ Diet } & Soy extract increases PPAR $\alpha$ and $\gamma$ in macrophages & In vitro & Mezei et al. [28] \\
\hline & $\begin{array}{l}\text { High-fat diet increases adipose tissue expression of } \\
\text { PPAR } \gamma \text { and induces PPAR } \gamma 2 \text { mRNA expression in liver } \\
\text { (obese mice) }\end{array}$ & Murine & Vidal-Puig et al. [26] \\
\hline & Hyperlipid diet reduces PPAR $\gamma$ in colonic epithelium & Murine & Delage et al. [29] \\
\hline & Low-calorie diet decreases PPAR $\gamma$ in subcutaneous fat & Human & Bastard et al. [27] \\
\hline \multirow{3}{*}{ Exercise } & Increases PPAR $\gamma$ DNA binding activity in fat depots & Murine & Petridou et al. [30] \\
\hline & Increases PPAR $\alpha$ in heart & Murine & Iemitsu et al. [24] \\
\hline & Increases $\operatorname{PPAR} \beta / \delta$ in skeletal muscle & Human & Fritz et al. [34] \\
\hline Obesity & $\begin{array}{l}\text { Increases of PPAR } \gamma 2 \text { and PPAR } \gamma 2 / \mathrm{PPAR} \gamma 1 \text { ratio in adi- } \\
\text { pose tissue }\end{array}$ & Human & Vidal-Puig et al. [31] \\
\hline Metabolic syndrome & $\begin{array}{l}\text { Dominant-negative mutation in } \operatorname{PPAR} \gamma \text { induces } \\
\text { metabolic syndrome }\end{array}$ & Human & Savage et al. [35] \\
\hline \multirow{2}{*}{ Insulin resistance (IR) } & Pioglitazone ameliorates IR & Murine & Ding et al. [33] \\
\hline & $\operatorname{PPAR} \gamma$ Ala allele protects against hyperinsulinemia & Human & Jaziri et al. [32] \\
\hline Vitamin A & Increases PPAR $\gamma$ in colonic mucosa & Murine & Delage et al. [29] \\
\hline
\end{tabular}

TABLE 2: Effects of metabolic conditions on pregnancy-specific diseases (GDM: gestational diabetes mellitus; PE: preeclampsia; IUGR: Intrauterine growth restriction; -: reduced risk; +: increased risk).

\begin{tabular}{lcccl}
\hline & \multicolumn{4}{c}{ Influence on pregnancy-specific diseases } \\
Conditions & GDM & PE & IUGR & Reference \\
\hline Diabetes & - & + & - & Ostlund et al. [36] \\
Advanced maternal age & + & + & + & Delbaere et al. [53] Odibo et al. [37] \\
$\begin{array}{l}\text { Hypertension } \\
\text { Optimal nutrition }\end{array}$ & - & + & + & Sibai et al. [38] \\
\hline Optimal exercise & - & - & - & Artal et al. [41] Saftlas et al. [43] Scholl et al. [39] \\
\hline Obesity & - & - & - & Artal et al. [41] Zhang et al. [44] Sorensen et al. [42] \\
\hline $\begin{array}{l}\text { Metabolic syndrome } \\
\text { Insulin resistance }\end{array}$ & + & + & + & Cedergren [48] Saftlas et al. [43] O'Brien et al. [47] Ros \\
Periconceptional multivitamins & - & + & + & et al. [45] Sebire et al. [46] Bodnar et al. [49] \\
\hline
\end{tabular}

pathophysiological conditions that modulate the PPAR system [22-35] influence the risk and course of preeclampsia (PE), gestational diabetes mellitus (GDM), or intrauterine growth restriction (IUGR) [36-53]. Some of these diseases and factors involving the PPAR system are summarized in Tables 1 and 2 .

In early pregnancy, immediately after embryonic implantation, major maternal physiologic changes occur in the cardiovascular, hepatic, and endocrine systems with resultant anatomical and metabolic modifications that serve to promote maternal immune tolerance of the conceptus and to provide the fetus with its increased nutritional needs $[54,55]$.
Metabolic changes (including increased availability of glucose, low density lipoprotein, and fatty acids) increased insulin resistance and altered amino acid metabolism, immunologic, and hematologic changes (including an increase in plasma volume). Establishment of a thrombophilic state and extensive placental and decidual angiogenesis are observed in pregnancy, and these changes require a complex activation of regulating mediators [56-58].

Pregnancy complications result when the mother and/or fetus fail to adapt to these new metabolic, angiogenic, and thrombogenic challenges. Women with preexisting compromise to their vascular homeostasis, such as underlying 
TABLE 3: PPAR knock out models and placental pathology (PRIP: peroxisome proliferator-activated receptor-(PPAR) interacting protein; RAP 250: nuclear receptor-activating protein 250).

\begin{tabular}{llcl}
\hline PPAR knockout model & Placental pathology & Lethality & Reference \\
\hline PPAR $\alpha$ & No significant effect on placentation & $20 \%$ & Yessoufou et al. [76] \\
PPAR $\beta / \delta$ & Poor placentation & $>90 \%$ & Barak et al. [77] \\
PPAR $\gamma$ & Poorly developed labyrinth & $100 \%$ & Barak et al. [15] Kubota et al. [82] \\
PPAR $\gamma$ coactivator PRIP & Reduced spongiotrophoblast layer & $100 \%$ & Zhu et al. [79] \\
PPAR $\gamma$ coactivator RAP250 & Reduced spongiotrophoblast layer & $100 \%$ & Antonson et al. [80] \\
RXR $\alpha$ or $\beta$ & Lack of labyrinth zone & $100 \%$ & Sapin et al. [81] \\
\hline
\end{tabular}

hypertension, diabetes mellitus, or metabolic syndrome, have a significantly increased risk of developing pregnancy complications (see Table 2). Placenta-associated complications also can lead to impaired growth or fetal demise $[59,60]$. These placental conditions share vasculopathological mechanisms in common with atherosclerosis and represent early markers for maternal risk of cardiovascular disease $[61,62]$ and hypertension $[61,63,64]$. Curiously, a prior history of preeclampsia appears to confer protection against the future development of endometriosis and some cancers $[65,66]$.

PPARs can be activated by natural ligands, like prostaglandins (PGs), fatty acids, and their derivatives, as well as by synthetic ligands. PPAR medications have been developedand discovered to be relatively safe drugs with benefits in multiple disease states including diabetes and cardiovascular disease [67]. Fibrate drugs used to treat hyperlipidemia, and thiazolidinedione drugs used to treat type 2 diabetes are potent and relatively specific ligand activators of $\operatorname{PPAR} \alpha$ and $\gamma$, respectively, and are widely used clinically $[68,69]$. A number of naturally-occurring PPAR ligands have been identified, including long-chain fatty acids (C16 and greater), eicosanoids such as 8(S)-HETE (PPAR $\alpha)$ and 9and13-HODE $(\operatorname{PPAR} \gamma)$, and PGs such as $\mathrm{PGA}_{1}$, which binds to $\operatorname{PPAR} \alpha, \operatorname{PPAR} \beta / \delta$, and 15 -deoxy-delta ${ }^{12,14}$-prostaglandin $\mathrm{J}_{2}\left(15 \mathrm{dPGJ}_{2}\right)$, which in turn binds to PPAR $\gamma$ [70-72]. Both the expression of PPAR and the production of their potential ligands are altered during pregnancy and its related diseases. We postulate that pathologic diversion of fatty-acid metabolism away from the production of eicosanoid ligands in preeclampsia and gestational diabetes might be corrected using synthetic ligands.

\section{PPARS IN TROPHOBLAST INVASION AND PLACENTAL DEVELOPMENT}

In first trimester, human placental bed biopsies, PPAR- $\gamma$ is expressed predominantly in invasive trophoblasts, whereas in the second-trimester PPAR $\gamma$ is expressed in the columns of anchoring villi and cytotrophoblasts [73, 74]. In the third trimester, PPAR $\gamma$ principally localizes to extravillous cytotrophoblasts (EVCT) and villous syncytiotrophoblasts [75], where it appears to regulate placental hormone production and secretion. Although the focus of this review is to summarize findings on PPAR/RXR heterodimers in human placentation, much of the direct evidence for a role of these receptors in trophoblast invasion and placental development has emerged from studies in knockout mouse models. This topic is reviewed comprehensively in Schaiff et al. [3], and is summarized briefly here and in Table 3 [76-81].

$\operatorname{PPAR} \gamma / \mathrm{RXR} \alpha$ heterodimers play a key regulatory role in murine placental development. PPAR $\gamma$ deficiency was shown to interfere with terminal trophoblast differentiation and placental vascularization [78]; embryos without this gene show massive placental defects that can be rescued by restoration of the trophoblast PPAR $\gamma$ gene via tetraploid chimeras [15]. Deletion of $\operatorname{RXR} \alpha$ and $\operatorname{RXR} \beta$ also leads to embryo lethality $[15,81,83]$. Both PPAR-interacting protein (PRIP) and nuclear receptor-activating protein 250 (RAP250) encode nuclear receptor coactivators that associate with PPARs, RXRs, and other nuclear receptor proteins. Genetic disruption of PRIP or RAP250 in mouse models results in embryonic lethality at postconception days 11.5 and 13.5 , respectively $[79,80]$. Placentas of PRIP $(-/-)$ and RAP250 $(-/-)$ embryos exhibited dramatically reduced spongiotrophoblast and labyrinth layers as well as failure of blood vessel maturation in the region bordering the spongiotrophoblast $[79,80]$.

In addition to placentation per se, $\operatorname{PAAR} \gamma$ appears to play an important role in the uterine preparation for embryonic implantation. Peeters et al. demonstrated that PPAR $\gamma$ ligands reduced the production of the endometrial angiogenic factor VEGF, and postulated that this pathway might influence early embryonic vascularization [84]. By contrast, PPAR $\gamma$ agonists induce angiogenesis in cardiac myofibroblasts, smooth muscle cells, and macrophages [85-87]. Recent preliminary data by our lab and others suggest that the PPAR $\gamma$ system also stimulates VEGF expression in trophoblast (JEG-3) cells (Depoix et al., unpublished).

The functional role of PPAR $\gamma$ activity is well studied in trophoblast physiology (Table 4). PPAR $\gamma$ agonists inhibit invasion of cultured EVCT isolated from human first-trimester placenta, whereas PPAR $\gamma$ antagonists promoted EVCT invasion and repressed the PPAR $\gamma$ agonist-mediated effects [78]. PPAR $\gamma$ controls mucin (MUC)-1 transcription and regulates maternal-fetal transport in mouse models [88]. Moreover, PPAR $\gamma$ and $\operatorname{RXR} \alpha$ play a role in human chorionic gonadotropin (hCG) expression, trophoblast differentiation, and regulation of fatty acid transport and storage in human placental trophoblasts $[89,90]$. PPAR $\gamma$ diminishes leptininduced inflammatory responses in the human placenta [91] and inhibits PAPP-A expression [92]. 
TABLE 4: PPAR action in trophoblast development and placental function (MUC-1: mucin-1; EVCT: extravillous cytotrophoblast; hCG: human chorionic gonadotropin; Th2 T-helper 2 cell).

\begin{tabular}{|c|c|c|c|}
\hline \multicolumn{4}{|c|}{ PPAR action in trophoblast development and placentation } \\
\hline PPAR & PPAR action & Model & Reference \\
\hline \multirow{10}{*}{ PPAR $\gamma$} & Inhibits EVCT invasion & In vitro & Fournier et al. [78] \\
\hline & Promotes trophoblast differentiation hCG secretion & In vitro & Tarrade et al. [89] \\
\hline & Induces hCG production & In vitro & Schild et al. [93] \\
\hline & Antiinflammatory & In vitro & Lappas et al. [91] \\
\hline & Regulates fatty acid transport & In vitro & Schaiff et al. [90] \\
\hline & Increases VEGF expression & In vitro & Depoix, unpublished \\
\hline & Terminal differentiation, placental vascularization & Murine & Barak et al. [15] \\
\hline & Controls MUC-1 expression & Murine & Shalom-Barak et al. [88] \\
\hline & Stimulates trophoblast maturation & Murine & Asami-Miyagishi et al. [94] \\
\hline & Modulates placental lipid metabolism & Murine & Capobianco et al. [95] \\
\hline $\mathrm{PPAR} \beta / \delta$ & Promotes placental development & Murine & Nadra et al. [8] \\
\hline $\operatorname{PPAR} \alpha$ & Regulates placental lipid transfer & Murine/Human & Wang et al. [74] \\
\hline \multicolumn{4}{|c|}{ PPAR action in pregnancy } \\
\hline \multirow{4}{*}{$\operatorname{PPAR} \gamma$} & Antiinflammatory & In vitro & Lappas et al. [96] \\
\hline & Involved in inflammatory control and remodeling in the placenta & In vitro & Marvin et al. [97] \\
\hline & Increased circulating PPAR $\gamma$ activators in normal pregnancy & In vitro/human & Waite et al. [73] \\
\hline & Decreases in fetal membrane with labor & Human & Dunn-Albanese et al. [98] \\
\hline $\operatorname{PPAR} \beta / \delta$ & Increases in amnion with labor & Human & Berry et al. [99] \\
\hline \multirow{2}{*}{$\operatorname{PPAR} \alpha$} & Stimulates Th2 cytokine pattern during pregnancy & Murine & Yessoufou et al. [76] \\
\hline & Declines in choriodecidua with labor & Human & Berry et al. [99] \\
\hline
\end{tabular}

Regulation of PPAR $y$ in human placental tissues is thought to occur through natural ligands (e.g., 15dPGJ2, 9HODE, 13-HODE, and 15-HETE) through direct binding to the receptor's ligand binding pocket $[11,100]$. These ligands are likely to be synthesized locally within the placenta. Furthermore, crosstalk between the mitogen-activated protein kinase (MAPK) p38 and PPAR $\gamma$ occurs within cultured trophoblast cells [101]. PPAR $\gamma$ decreases IGFII secretion and is thought to inhibit trophoblast invasion via the PAPP-A cascade [92].

In young PPAR $\alpha$ knock out mice, no major phenotypic differences of gross pathology of internal organs were described $[76,102]$. However, disturbance of the Th1/Th2 Tlymphocyte ratio, rather than placental malformation, is thought to be responsible for an increased abortion rate (20\%) in PPAR $\alpha$ null mice. During normal pregnancy Th1 cytokines are downregulated and Th2 cytokines are upregulated [103].

The third distinct PPAR, PPAR $\beta / \delta$ also is essential for placentation as demonstrated in $\operatorname{PPAR} \beta / \delta$ knockout mice (Table 3) [77], and is involved in the regulation of implantation in other animal models $[17,104,105]$. The implantation of cultured embryos is enhanced by $\operatorname{PPAR} \beta / \delta$ activation and this receptor even has been postulated as a novel therapeutic target to improve clinical IVF outcomes [104]. PPAR $\beta / \delta$ is induced during decidualization of the implantation site and requires close contact with the blastocyst. $\operatorname{PPAR} \beta / \delta$ null mice die between 9.5 to 10.5 embryonic days due to abnormal cellcell communication at the placental-decidual interface [8].
Together these data suggest that PPARs are required not only for trophoblast invasion and differentiation but also for establishment of the placental maternal-fetal transport.

\section{PPARS AND PREGNANCY}

Based on its regulatory functions and known eicosanoid ligands, PPAR $\gamma$ has emerged as an excellent candidate to play a role in the regulation of maternal metabolism, maintenance of uterine quiescence, and onset of labor by regulating proinflammatory cytokines and prostaglandins (Table 4). Normal pregnancy is accompanied by changes in lipid and glucose metabolism, but further dysregulation of these pathways can lead to pregnancy complications such as PE or GDM. Hence, PPAR regulators of these metabolic pathways might be expected to be important in human pregnancy.

Some of our initial studies in this field were designed to screen for potential activators of PPAR $\gamma$ in the circulation of pregnant women. Human choriocarcinoma JEG-3 cells were transfected with peroxisome-proliferator responsive reporter plasmids; and pooled sera from pregnant and nonpregnant women were added to the cell culture medium [73]. Peroxisome proliferator responsive element (PPRE) luciferase reporter activation was dramatically increased by sera from pregnant women compared to nonpregnant women (Figures 1 and 2). We showed that PPARy (and to some extent $\operatorname{PPAR} \alpha$ ) activity is increased from the earliest stages of pregnancy (Figure 2). The findings suggested that circulating PPAR $\gamma$-activating factors, presumably eicosanoids, were 


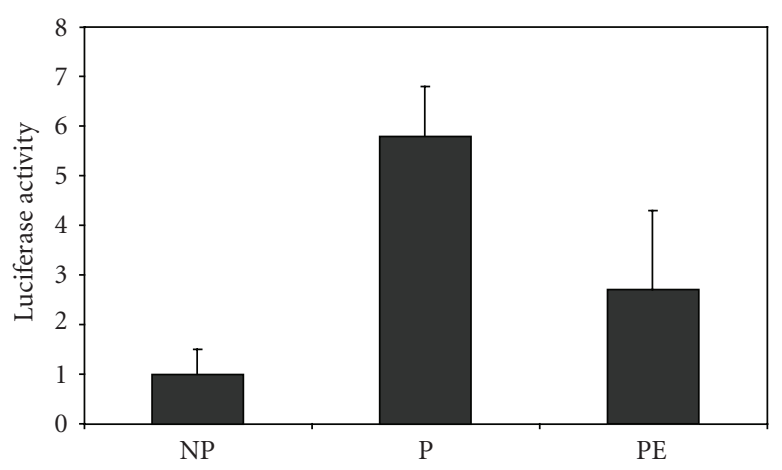

FIGURE 1: JEG-3 cells were transfected with PPRE-luciferase reporter vectors and treated with pooled sera (10\%) from nonpregnant (NP), pregnant (P) and preeclamptic (PE) women. Luciferase acitivity, relative to cells treated with $10 \%$ dextran charcoalshipped fetal calf serum (DCSS), is reported on the ordinate.

present throughout the course of gestation. We hypothesized that activation of PPAR $\gamma$ by sera of pregnant women is a regulatory adaptation of the maternal organism to increased lipid and glucose loading in pregnancy [73].

It also has been hypothesized that PPAR $\gamma$ activation regulates uterine quiescence by influencing Nuclear FactorKappa B (NF $\kappa$ B) and cyclooxygenase (COX-2) expression $[96,97,106]$. Reciprocal expression of PPAR $\gamma$ and (COX)2 in human term placenta suggests a role of the PPAR system in the initiation of labor [98]. Under conditions of high PPAR $\gamma$ expression, antiinflammatory actions dominate; however, with onset of labor PPAR $\gamma$ levels drop and COX2 concomitantly increases in the fetal membranes [98]. Elevated COX-2 activity in the human amnion is observed in the settings of term and idiopathic preterm labor, contributing to the generation of uterotonic prostaglandins (PGs), which are known to participate in parturition [107]. PPAR $\gamma$ ligands have been shown to antagonize NF- $\kappa \mathrm{B}$ activation and reduce inflammatory cytokine gene expression (IL-1 $\beta$, IL-6, IL-10 and TNF- $\alpha$ ) and COX-2 [108]. Both natural (e.g., 15dPGJ2) and synthetic ligands (e.g., troglitazone) were shown to have anti-inflammatory effects in human gestational tissues, significantly decreasing basal and LPS-stimulated $\mathrm{PGE}_{2}$ and $\mathrm{PGF}_{2 \alpha}$ release from placenta and amnion [108]. $\mathrm{PGF}_{2 \alpha}$, also a marker of oxidative stress, is increased in women with preeclampsia [109]. Given the inflammatory changes observed in pregnancy-specific diseases, a potential role of PPAR agonist treatment has been entertained for the treatment of PE, GDM, and other pregnancy-specific diseases such as the prevention of preterm labor [96].

PPAR $\alpha$ and $\beta / \delta$ also play a role in maintaining pregnancy and parturition. PPAR $\alpha$ and $\beta / \delta$ are expressed in the amnion, choriodecidua, and villous placental tissues. Data from $\operatorname{PPAR} \alpha$ knockout mice suggest that $\operatorname{PPAR} \alpha$ maintains pregnancy by stimulating a Th2 cytokine response [76]. In normal pregnancy, expression of PPAR $\alpha$ declines in the choriodecidua with the onset of labor [99]. By contrast, PPAR $\beta / \delta$ expression, which is temporally upregulated between the first and third trimester of pregnancy [99], increases further in the amnion coincidental with the onset of labor [99].

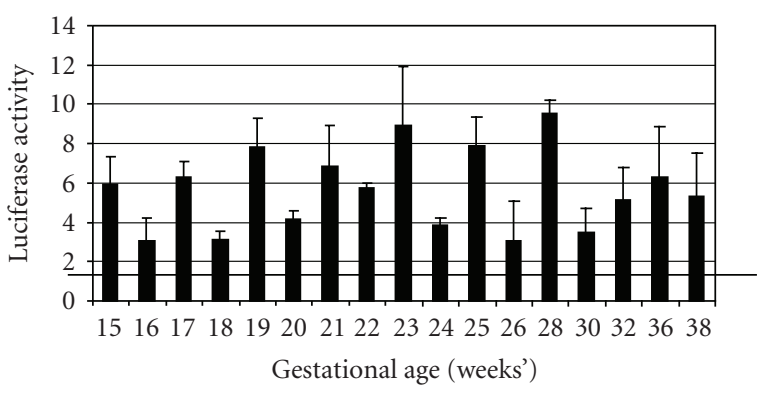

FIGURE 2: PPAR $\gamma$ activation is present throughout the course of normal pregnancy. All serum samples were collected from the same subject and PPRE-luciferase reporter experiments were performed using $10 \%$ serum as described in Figure 1. Luciferase activity was normalized to DCSS to determine relative activation. Black horizontal bar represents the level of signaling seen with $10 \%$ serum from the same woman six weeks after delivery.

Few studies have elucidated substantial risk of PPAR agonists during pregnancy in animal models, but these drugs carry a "C" classification from the FDA. For example, rosiglitazone did not damage blastocyst development in vitro or harm mouse fetuses when given during murine pregnancy [110]. While the use of rosiglitazone during pregnancy is generally considered to be safe [110]; more data need to be acquired before these drugs can be recommended.

\section{PPARs AND PREGNANCY-SPECIFIC DISEASES}

Failure of metabolic adaptation to pregnancy can result in pregnancy-specific complications such as PE and GDM. We and others have postulated that angiogenic factors and cytokines that lead to pathological gestational changes are likely to be regulated by the PPAR system (Table 5).

\subsection{PPARs and preeclampsia}

PE is a multifactorial, pregnancy-related disorder that is defined by new-onset hypertension and proteinuria after 20 weeks of gestation [117]. PE is a common cause of maternal and infant morbidity and mortality worldwide, and is responsible for about $20 \%$ of pregnancy-related maternal deaths in the US [118]. Women with PE have increased insulin resistance as well as hypertriglyceridemia relative to normal pregnant women [119]. To date, no effective treatment has been found that either prevents or reverses the development of the disease. Modern concepts of PE pathophysiology invoke a two-stage process. The first stage is believed to be initiated by impaired trophoblast invasion and abnormal uterine vessel remodeling. The second stage is postulated to result from circulating factors claimed to be derived from the ischemic placenta that stimulate an inflammatory activation of maternal vascular endothelial cells. PE presents clinically in the second or third trimester, however, fundamental inflammatory and angiogenic biomarkers in the serum are detectable as early as the first trimester in women with PE. Elevated concentrations of IL-2, TNF $\alpha$, and sVEGFR-1 
TABLE 5: PPAR in pregnancy-specific diseases.

\begin{tabular}{llccc}
\hline PPAR & PPAR-action & Disease & Model & Reference \\
\hline & Reduced circulating PPAR $\gamma$ activators in serum from & PE & In vitro & Waite et al. [111] \\
& women with PE & GDM & Murine & Capobianco et al. [95] \\
& Placental 15dPGJ ${ }_{2}$ level are decreased in diabetes & GDM & Human & Tok et al. [112] \\
PPAR $\gamma$ & Association of PPAR- $\gamma$ 2 Pro12Ala with weight gain & GDM & Human & Javerbaum et al. [113] \\
& Placental 15dPGJ ${ }_{2}$ levels are decreased & Hydatidiform mole & Human & Capparuccia et al. [114] \\
& Decreased & Choriocarcinoma & Human & Capparuccia et al. [114] \\
& Decreased & IUGR & Human & Rodie et al. [115] \\
& Placental PPAR expression is not involved & Preterm birth & Human & Meirhaeghe et al. [116] \\
\hline PPAR $\alpha$ & Association of PPAR- $\gamma$ 2 Pro12Ala polymorphism & Abortion/neonatal mortality & Murine & Yessoufou et al. [76] \\
\hline
\end{tabular}

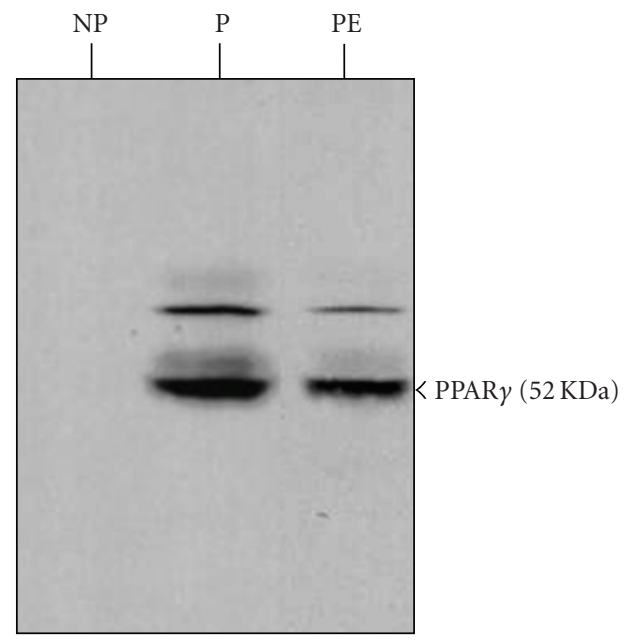

FIGURE 3: Immunoblot of JEG-3 cells treated with pooled sera $(10 \%)$ from nonpregnant (NP), pregnant $(\mathrm{P})$, and preeclamptic (PE) women. Cell lysates were analyzed using a specific mouse antihuman PPAR $\gamma$ monoclonal antibody. Equal amounts of protein $(50 \mu \mathrm{g})$ were loaded into each lane. Factors in pregnant serum upregulate JEG-3 PPAR $\gamma$ expression. A decrease in PPAR $\gamma$ protein was observed in cells exposed to PE sera (PE) compared to sera from normal pregnant women $(\mathrm{P})$.

and reduced concentrations of PlGF, IGFBP-1, and HLA-G in the maternal serum precede the clinical manifestations of PE [119-123].

While the cause of PE remains unknown, several environmental and genetic risk factors have been identified (Table 2). Relevant to this review are hypertension, diabetes, and high (>29) body mass index (BMI) $[47,124,125]$. Black race also appears to be a risk factor for PE [126] although this may be confounded by increased rates of the above risk factors. Key inflammatory and angiogenic pathways involved in the pathogenesis of PE are regulated by the PPAR system, which itself is influenced by environmental and genetic factors. We believe that exogenous and endogenous lipid regulators of PPAR play a role in maternal metabolism and immune functionin normal and pathological pregnancies. For example, dietary factors and physical activity that modulate the PPAR system have been shown to reduce the risk and course of PE (Table 2).

Similarly, genetic variations in the PPAR $y$ gene have been proposed to modify the risk of PE. For example, the Pro467Leu mutation of PPAR $\gamma$ [127-129] is a dominant negative mutant resulting from a C-to-T transition in exon 6 . A report of two individuals (one woman, one man) with this mutation showed that they developed type 2 diabetes at young ages (26 and 27 years at diagnosis), as well as early hypertension ( 37 and 27 years at diagnosis). Intriguingly, the woman had two pregnancies, both of which were complicated by severe PE. The Pro12Ala polymorphism occurs in PPAR $\gamma 2$ [130], a second isoform of PPAR $\gamma$ that is expressed mainly in adipose tissue. This mutation is the result of a C-to-G transversion in exon B. This is by far the most studied allelic variation in any PPAR, and occurs at a rate of about $12 \%$ in the Caucasian US population. While the resulting phenotype is highly diverse and even apparently contradictory, it appears that the penetrance of this mutation is influenced by other genetic, environmental, ethnic, and gender differences. The studies generally agree that the presence of the Ala allele is associated with increased BMI, an independent risk factor for PE. Thus, this polymorphism is a candidate affecting pregnancy outcome. Preliminary data of a study on the PPAR gene variations (in PPAR gene) showed no association with $\mathrm{PE}$ or severity of PE in a Finnish population [131]. Further studies on the association of PPAR $\alpha, \beta$, and $\gamma$ gene variations of mothers and offspring and pregnancy-specific diseases need to be performed in different ethnic populations.

$\mathrm{PE}$ is marked by hyperlipidemia, and is characterized by a state of oxidative stress. Circulating lipids in PE women are more highly oxidized, and oxidized low-density lipoproteins (oxLDLs), in particular, are highly elevated [132]. Given the circulating plasma lipid disturbances in PE, our group performed experiments comparing sera from normal and PE patients. We found that serum from women with severe PE had reduced levels of PPAR activating lipids compared with serum of parity and gestational age-matched women and also diminished the expression of PPAR $\gamma$ in trophoblast cells (Figures 1 and 3) [111]. The reduction of transcriptional 
activity observed in preeclamptic women's sera was shown for PPAR $\gamma$ and PPAR $\alpha$, however not for PPAR $\beta / \delta$ or RXR. The reduction in potential circulating PPAR activatorswas observed weeks and sometimes months before the onset of maternal symptoms and clinicaldiagnosis of PE [133]. Our results are consistent with other clinical evidence that antiinflammatory regulation is challenged and further compromised in the maternal syndrome of PE. Normal pregnancy manifests as a physiologic inflammatory state postulated to be tolerated to serve the nutritional needs of the fetus, whereas, in PE regulatory inflammatory mechanisms are excessively amplified, leading to vascular damage in the mother [133]. In this "hyperinflammatory" state of PE [134], the cytokines TNF $\alpha$ and IL- $1 \beta$ which are typically controlled by the NF- $\kappa$ B pathway in a negative-feedback loop with PPAR, are elevated [26, 60, 119]. Elevated inflammatory parameters in PE accompany altered levels of PG metabolites and circulating fatty acids. As noted, PG metabolites as well as fatty acids are important ligands of the PPAR system [135]. PG metabolism is altered during normal pregnancy with levels of vasorelaxants suchas prostacyclin increasing, whereas vasoconstrictive prostaglandin levelstend to be suppressed [136]. Failure of these alterations have been suggested to lead to pregnancy complications (e.g., PE) [137]. For example, $\mathrm{PGF}_{2 \alpha}$, which itself is stimulated by factorsin the plasma of women with PE [138], can inhibit PPAR $\gamma$ effects [135]. Levelsof circulating free fatty acids are in the normal range duringmost of pregnancy, but rise dramatically during the final weeks of pregnancy and drop precipitously at term [136]. In PE these levels are increased from 20 weeks' gestation [133, 139]. We postulate that altered PG metabolism in this setting [138] results in decreased PPAR $\gamma$ ligation and subsequent cytokine activation. If this proposal is supported by more data, the use of PPAR ligands might be proposed to ameliorate symptoms such as hypertension and inflammation. Unfortunately, at present, the mechanism and site of this salutary of PPAR ligand effect remain unknown in pregnancy, confounded by PPAR expression in many cell types, including endothelial cells.

\subsection{PPARs and gestational diabetes}

During normal pregnancy, maternal lipid, and glucose metabolism is profoundly altered [140]. The developing fetus uses glucose as its predominant energy source, which puts a continuous demand on the mother to provide this substrate [141]. This constant need for glucose results in frequent hypoglycemia and postprandial hyperglycemia during normal pregnancy [141]. Problems with energy metabolism such as GDM are not uncommon and are often observed in susceptible women at this time. GDM is defined as any degreeof glucose intolerance with onset or first recognition during pregnancy. In women with GDM, defective $\beta$-cells function cannot adequately compensate for free fatty acidmediated insulin resistance [142]. As elsewhere in our society, the incidence of obesity, diabetes, and gestational diabetes mellitus are increasing in the pregnant population [143]. In the United States, the incidence of obesity among pregnant women ranges from $18.5 \%$ to $38.3 \%$ [144]; obesity comprises a major risk factor for GDM [145]. Morphological changes have been identified in the syncytiotrophoblast, cytotrophoblast, trophoblastic basement membrane, and fetal vessels within the placentae of these cases [146]. GDM is associated with several severe neonatal complications (such as macrosomia, brachial plexus palsy, premature delivery, IUGR, and intrauterine death) and maternal birth injuries also are common $[125,147]$. Furthermore, GDM has emerged as a risk factor for the development of diabetes mellitus type 2 (DM2) and cardiovascular disease in later life and shares a number of epidemiologic, pathophysiologic, and genetic characteristics with DM2 [148]. GDM also has detrimental effects on the postnatal infants [149].

The PPAR system regulates the metabolic and pathways involved in the establishment of GDM. PPAR-agonists have antidiabetogenic, antiinflammatory, and antioxidant effects, which are all potentially beneficial in the treatment of GDM [5].

Environmental factors, such as diet and exercise and genetic factors influence $\operatorname{PPAR} \alpha, \gamma$ activity $[130,150]$ as well as the risk for insulin resistance and GDM (Table 2). Exercise activity initiated prepregnancy was shown to reduce the risk of GDM and its complications [40, 41, 44, 151, 152]. Nutritional counseling, moderate physical exercise, weight loss, and diet are successful therapies in some women with GDM, improving glycemic control, reducing the incidence of LGA infants, and decreasing the need for cesarean deliveries for cephalopelvic disproportion $[41,153]$.

Candidate genes for GDM risk include $\mathrm{TNF} \alpha, \beta 3$ adrenoreceptor (ADRB3), and PPAR $\alpha$ and $\gamma$. The PPAR $\gamma$ Pro12Ala polymorphism was not associated with increased insulin resistance in Turkish women with GDM, however it was associated with weight gain [112]. The PPAR $\gamma$ coactivator-1alpha (PGC-1) polymorphism also failed to be associated with the development of GDM [154]. More studies on the association of various genetic PPAR $\alpha$ and $\gamma$ variants and GDM in different ethnic populations will be of interest.

$15 \mathrm{dPGJ}_{2}$ is a potent antiinflammatory agent that represses the expression of a number of inflammatory genes and regulating factors including the transcription factor NF$\kappa \mathrm{B}[33,108]$. The concentration of $15 \mathrm{dPGJ}_{2}$ was reduced in placentae from diabetic rats (Table 5) [95]. Placental $15 \mathrm{dPGJ}_{2}$ was noted to be diminished in women with gestational and pregestational diabetes when compared to controls, whereas levels of nitric oxide (a stimulator of placental invasiveness, differentiation, and proliferation) were higher in term placental explants from diabetic patients when compared to controls [113]. As PPAR $\gamma$ can prevent nitric oxide overproduction in placenta from pregestational diabetic women [113], it may have the potential to improve fetal outcome in this condition.

Sulfonylurea agents including gliumepiride and glibenclamide exhibit PPAR $\gamma$ activity [155]. A randomized controlled trial to test the effectiveness and safety of the sulfonylurea agent glyburide in the management of women with GDM showed similar efficacy to insulin treatment [156]. Both the insulin- and glyburide-treated women were able to 
achieve satisfactory glucose control and had similar perinatal outcome [156].

\subsection{PPARs and other pregnancy-specific diseases}

Trophoblast research has emphasized the similarities between the proliferative, migratory, andinvasive properties of placental cells and those of cancer cells [157]. PPAR $\gamma$, $\operatorname{PPAR} \beta / \delta$, and RXR appear to be linked to gestational trophoblastic neoplasms, conditions associated with malignant trophoblast behavior [114]. PPAR $\gamma$ agonists inhibit invasion of normal extravillous cytotrophoblast isolated from human first-trimester placenta, and PPAR activity has been shown to be downregulated in trophoblastic diseases including hydatidiform mole and choriocarcinoma [114].

PPAR $\gamma$ has an effect on fetal and placental size influencing intrauterine growth. In an intrauterine growth restriction (IUGR) model, glucocorticoids inhibited fetal and placental growth partly by suppression of PPAR $\gamma$ in the labyrinth zone of the placenta [158]. Activation of PPAR $\gamma$ in the labyrinth trophoblasts is hypothesized to induce angiogenic factors and stimulate the growth of fetal blood vessels, thereby promoting placental growth. However, treatment of pregnant mice with rosiglitazone led to reduced thickness of the spongiotrophoblast layer and the surface area of labyrinthine vasculature, and it altered expression of proteins implicated in placental development [159].

In vitro and in vivo experiments as well as animal models studies suggest a link between the PPAR system and gestational duration, preterm labor, and birth weight [116]. Variations in the PPAR genes influence other pregnancy-related mechanisms including birth weight and gestational duration. In an Irish population, the PPAR $\gamma$ Ala12 allele was associated with shorter gestational duration [116].

PPAR ligands regulate apoptotic mechanisms involved in rupture of the fetal membranes and may play a role in preterm delivery, a condition associated with increased risk of neonatal sepsis and newborn trauma [160]. 15d$\mathrm{PGJ}_{2}$ induced morphological characteristics of apoptosis within 2 hours in an amniotic cell line [160]. In addition, ciglitizone also induced apoptosis, whereas rosiglitazone had no effect on cell viability [160]. Prevention of apoptosis may have therapeutic potential in preterm labor and premature rupture of the membranes and necessitates further investigations.

Interestingly, PPAR $\alpha$ deficiency is associated with miscarriage, neonatal mortality, and a shift from Th2 to a Th1 cytokine phenotype [76]. Th1 predominant immunity is closely associated with inflammation, endothelial dysfunction, and pregnancy complications. For example, interferon $\gamma$ is significantly reduced in the spleens of $\operatorname{PPAR} \alpha$ null mice [76]. Twenty percent of PPAR $\alpha$ knockout mice aborted, and offspring of PPAR- $\alpha$ null mice exhibited increased neonatal mortality (13.3\%). However the mechanism whereby PPAR $\alpha$ induces a Th2 phenotype shift remains to be determined. PPAR $\gamma$ ligands also were shown to decrease production of inflammatory ligands in activated macrophages and $\mathrm{T}$ cells and to induce a shift from Th1 to Th2 cytokine phenotype $[161,162]$.

\section{CONCLUSIONS}

PPARs are involved in trophoblast invasion, placental development, parturition, and pregnancy-specific diseases, particularly PE and GDM. The role of the PPAR system in pregnancy under physiologic and pathologic conditions has remained partly unclear due to lack of knowledge about endogenous PPAR ligands. Pharmacological ligand research is ahead of the identification of physiologic ligands. Partially characterized inflammatory, angiogenic, and metabolic disturbances in pregnancy-related diseases suggest that these synthetic PPAR agonists may be of potential use in these conditions. Ongoing basic studies have elucidated the metabolic, antiinflammatory, and angiogenic benefits of $\operatorname{PPAR} \alpha / \beta / \delta$ and $\operatorname{PPAR} \gamma / \beta / \delta$ dual agonists and PPAR pan agonists for treatment purposes. However, some experimental and clinical data have uncovered unfortunate side effects of PPAR ligands, including cancer progression and increased cardiac event rates. New generations of PPAR modulators are under development and these promise to be more receptor-specific, and hopefully will activate only a specific subset of target genes and metabolic pathways to reduce untoward side effects. The potential role of PPARs in regulation of inflammation and angiogenesis is intriguing and warrants further studies. We submit that PPAR agonists may become beneficial drugs for pregnancy-specific diseases, once their risks have been fully evaluated.

\section{ACKNOWLEDGMENT}

The authors' studies described in this article were supported by NIH Grants P01-HD30367 and R01-HL73469.

\section{REFERENCES}

[1] G. Rizzo and S. Fiorucci, "PPARs and other nuclear receptors in inflammation," Current Opinion in Pharmacology, vol. 6, no. 4, pp. 421-427, 2006.

[2] A. Margeli, G. Kouraklis, and S. Theocharis, "Peroxisome proliferator activated receptor- $\gamma$ (PPAR- $\gamma$ ) ligands and angiogenesis," Angiogenesis, vol. 6, no. 3, pp. 165-169, 2003.

[3] W. T. Schaiff, Y. Barak, and Y. Sadovsky, "The pleiotropic function of PPAR $y$ in the placenta," Molecular and Cellular Endocrinology, vol. 249, no. 1-2, pp. 10-15, 2006.

[4] P. Froment, F. Gizard, D. Defever, B. Staels, J. Dupont, and P. Monget, "Peroxisome proliferator-activated receptors in reproductive tissues: from gametogenesis to parturition," Journal of Endocrinology, vol. 189, no. 2, pp. 199-209, 2006.

[5] J. Berger and D. E. Moller, "The mechanisms of action of PPARs," Annual Review of Medicine, vol. 53, pp. 409-435, 2002.

[6] S. Kersten, B. Desvergne, and W. Wahli, "Roles of PPARs in health and disease," Nature, vol. 405, no. 6785, pp. 421-424, 2000.

[7] M. J. Holness, G. K. Greenwood, N. D. Smith, and M. C. Sugden, "Peroxisome proliferator-activated receptor- $\alpha$ and glucocorticoids interactively regulate insulin secretion during pregnancy," Diabetes, vol. 55, no. 12, pp. 3501-3508, 2006.

[8] K. Nadra, S. I. Anghel, E. Joye, et al., "Differentiation of trophoblast giant cells and their metabolic functions are dependent on peroxisome proliferator-activated receptor $\beta / \delta$," 
Molecular and Cellular Biology, vol. 26, no. 8, pp. 3266-3281, 2006.

[9] G. Krey, A. Mahfoudi, and W. Wahli, "Functional interactions of peroxisome proliferator-activated receptor, retinoid$\mathrm{X}$ receptor, and $\mathrm{Sp} 1$ in the transcriptional regulation of the acyl- coenzyme-A oxidase promoter," Molecular Endocrinology, vol. 9, no. 2, pp. 219-231, 1995.

[10] Y. Guan, Y. Zhang, L. Davis, and M. D. Breyer, "Expression of peroxisome proliferator-activated receptors in urinary tract of rabbits and humans," American Journal of Physiology - Renal Physiology, vol. 273, no. 6, pp. F1013-F1022, 1997.

[11] T. Fournier, V. Tsatsaris, K. Handschuh, and D. Evain-Brion, "PPARs and the placenta," Placenta, vol. 28, no. 2-3, pp. 6576, 2007.

[12] O. Braissant, F. Foufelle, C. Scotto, M. Dauça, and W. Wahli, "Differential expression of peroxisome proliferator-activated receptors (PPARs): tissue distribution of PPAR- $\alpha,-\beta$, and $-\gamma$ in the adult rat," Endocrinology, vol. 137, no. 1, pp. 354-366, 1996.

[13] L. Fajas, J.-C. Fruchart, and J. Auwerx, "PPAR $\gamma 3$ mRNA: a distinct PPAR $\gamma$ mRNA subtype transcribed from an independent promoter," FEBS Letters, vol. 438, no. 1-2, pp. 55-60, 1998.

[14] P. Peraldi, M. Xu, and B. M. Spiegelman, "Thiazolidinediones block tumor necrosis factor- $\alpha$-induced inhibition of insulin signaling," Journal of Clinical Investigation, vol. 100, no. 7, pp. 1863-1869, 1997.

[15] Y. Barak, M. C. Nelson, E. S. Ong, et al., "PPAR $\gamma$ is required for placental, cardiac, and adipose tissue development," Molecular Cell, vol. 4, no. 4, pp. 585-595, 1999.

[16] X. Zhang and H. A. Young, "PPAR and immune systemwhat do we know?" International Immunopharmacology, vol. 2, no. 8, pp. 1029-1044, 2002.

[17] E. Lord, B. D. Murphy, J. A. Desmarais, S. Ledoux, D. Beaudry, and M.-F. Palin, "Modulation of peroxisome proliferator-activated receptor $\delta$ and $\gamma$ transcripts in swine endometrial tissue during early gestation," Reproduction, vol. 131, no. 5, pp. 929-942, 2006.

[18] H. Higashiyama, A. N. Billin, Y. Okamoto, M. Kinoshita, and S. Asano, "Expression profiling of Peroxisome proliferatoractivated receptor- $\delta$ (PPAR- $\delta$ ) in mouse tissues using tissue microarray," Histochemistry and Cell Biology, vol. 127, no. 5, pp. 485-494, 2007.

[19] A. Chawla, Y. Barak, L. Nagy, D. Liao, P. Tontonoz, and R. M. Evans, "PPAR- $\gamma$ dependent and independent effects on macrophage-gene expression in lipid metabolism and inflammation," Nature Medicine, vol. 7, no. 1, pp. 48-52, 2001.

[20] D. K. Krämer, L. Al-Khalili, B. Guigas, Y. Leng, P. M. GarciaRoves, and A. Krook, "Role of AMP kinase and PPAR $\delta$ in the regulation of lipid and glucose metabolism in human skeletal muscle," Journal of Biological Chemistry, vol. 282, no. 27, pp. 19313-19320, 2007.

[21] M. Adjuik., A. Babiker, P. Garner, P. Olliaro, W. Taylor, and N. White, "Artesunate combinations for treatment of malaria: meta-analysis," The Lancet, vol. 363, no. 9402, pp. 9-17, 2004.

[22] K. S. Park, T. P. Ciaraldi, L. Abrams-Carter, S. Mudaliar, S. E. Nikoulina, and R. R. Henry, "PPAR- $\gamma$ gene expression is elevated in skeletal muscle of obese and type II diabetic subjects," Diabetes, vol. 46, no. 7, pp. 1230-1234, 1997.

[23] P. Imbeault, H. Vidal, A. Tremblay, et al., "Age-related differences in messenger ribonucleic acid expression of key proteins involved in adipose cell differentiation and metabolism," Journal of Clinical Endocrinology \& Metabolism, vol. 86, no. 2, pp. 828-833, 2001.
[24] M. Iemitsu, T. Miyauchi, S. Maeda, et al., "Aging-induced decrease in the PPAR- $\alpha$ level in hearts is improved by exercise training," American Journal of Physiology - Heart and Circulatory Physiology, vol. 283, no. 5, pp. H1750-H1760, 2002.

[25] Q. N. Diep and E. L. Schiffrin, "Increased expression of peroxisome proliferator-activated receptor- $\alpha$ and $-\gamma$ in blood vessels of spontaneously hypertensive rats," Hypertension, vol. 38, no. 2, pp. 249-254, 2001.

[26] A. Vidal-Puig, M. Jimenez-Liñan, B. B. Lowell, et al., "Regulation of PPAR $\gamma$ gene expression by nutrition and obesity in rodents," Journal of Clinical Investigation, vol. 97, no. 11, pp. 2553-2561, 1996.

[27] J. P. Bastard, B. Hainque, E. Dusserre, et al., "Peroxisome proliferator activated receptor- $\gamma$, leptin and tumor necrosis factor- $\alpha$ mRNA expression during very low calorie diet in subcutaneous adipose tissue in obese women," Diabetes/Metabolism Research and Reviews, vol. 15, no. 2, pp. 9298, 1999.

[28] O. Mezei, W. J. Banz, R. W. Steger, M. R. Peluso, T. A. Winters, and N. Shay, "Soy isoflavones exert antidiabetic and hypolipidemic effects through the PPAR pathways in obese zucker rats and murine RAW 264.7 cells," Journal of Nutrition, vol. 133, no. 5, pp. 1238-1243, 2003.

[29] B. Delage, C. Bairras, B. Buaud, V. Pallet, and P. Cassand, "A high-fat diet generates alterations in nuclear receptor expression: prevention by vitamin A and links with cyclooxygenase2 and $\beta$-catenin," International Journal of Cancer, vol. 116, no. 6, pp. 839-846, 2005.

[30] A. Petridou, S. Tsalouhidou, G. Tsalis, T. Schulz, H. Michna, and V. Mougios, "Long-term exercise increases the DNA binding activity of peroxisome proliferator-activated receptor $\gamma$ in rat adipose tissue," Metabolism, vol. 56, no. 8, pp. 1029-1036, 2007.

[31] A. J. Vidal-Puig, R. V. Considine, M. Jimenez-Liñan, et al., "Peroxisome proliferator-activated receptor gene expression in human tissues. Effects of obesity, weight loss, and regulation by insulin and glucocorticoids," Journal of Clinical Investigation, vol. 99, no. 10, pp. 2416-2422, 1997.

[32] R. Jaziri, S. Lobbens, R. Aubert, et al., "The PPARG Pro12Ala polymorphism is associated with a decreased risk of developing hyperglycemia over 6 years and combines with the effect of the APM1 G-11391A single nucleotide polymorphism," Diabetes, vol. 55, no. 4, pp. 1157-1162, 2006.

[33] S. Y. Ding, Z. F. Shen, Y. T. Chen, S. J. Sun, Q. Liu, and M. Z. Xie, "Pioglitazone can ameliorate insulin resistance in lowdose streptozotocin and high sucrose-fat diet induced obese rats," Acta Pharmacologica Sinica, vol. 26, no. 5, pp. 575-580, 2005.

[34] T. Fritz, D. K. Krämer, H. K. Karlsson, et al., "Lowintensity exercise increases skeletal muscle protein expression of PPAR $\delta$ and UCP3 in type 2 diabetic patients," Diabetes/Metabolism Research and Reviews, vol. 22, no. 6, pp. 492-498, 2006.

[35] D. B. Savage, G. D. Tan, C. L. Acerini, et al., "Human metabolic syndrome resulting from dominant-negative mutations in the nuclear receptor peroxisome proliferatoractivated receptor- $\gamma$," Diabetes, vol. 52, no. 4, pp. 910-917, 2003.

[36] I. Ostlund, B. Haglund, and U. Hanson, "Gestational diabetes and preeclampsia," European Journal of Obstetrics \& Gynecology and Reproductive Biology, vol. 113, no. 1, pp. 12-16, 2004.

[37] A. O. Odibo, D. Nelson, D. M. Stamilio, H. M. Sehdev, and G. A. Macones, "Advanced maternal age is an independent risk 
factor for intrauterine growth restriction," American Journal of Perinatology, vol. 23, no. 5, pp. 325-328, 2006.

[38] B. M. Sibai, M. Ewell, R. J. Levine, et al., "Risk factors associated with preeclampsia in healthy nulliparous women. The calcium for preeclampsia prevention (CPEP) study group," American Journal of Obstetrics \& Gynecology, vol. 177, no. 5, pp. 1003-1010, 1997.

[39] T. O. Scholl, M. Leskiw, X. Chen, M. Sims, and T. P. Stein, "Oxidative stress, diet, and the etiology of preeclampsia," American Journal of Clinical Nutrition, vol. 81, no. 6, pp. 1390-1396, 2005.

[40] C. Zhang, M. B. Schulze, C. G. Solomon, and F. B. Hu, "A prospective study of dietary patterns, meat intake and the risk of gestational diabetes mellitus," Diabetologia, vol. 49, no. 11, pp. 2604-1613, 2006.

[41] R. Artal, R. B. Catanzaro, J. A. Gavard, D. J. Mostello, and J. C. Friganza, "A lifestyle intervention of weight-gain restriction: diet and exercise in obese women with gestational diabetes mellitus," Applied Physiology, Nutrition, and Metabolism, vol. 32, no. 3, pp. 596-601, 2007.

[42] T. K. Sorensen, M. A. Williams, I. M. Lee, E. E. Dashow, M. L. Thompson, and D. A. Luthy, "Recreational physical activity during pregnancy and risk of preeclampsia," Hypertension, vol. 41, no. 6, pp. 1273-1280, 2003.

[43] A. F. Saftlas, N. Logsden-Sackett, W. Wang, R. Woolson, and M. B. Bracken, "Work, leisure-time physical activity, and risk of preeclampsia and gestational hypertension," American Journal of Epidemiology, vol. 160, no. 8, pp. 758-765, 2004.

[44] C. Zhang, C. G. Solomon, J. E. Manson, and F. B. Hu, "A prospective study of pregravid physical activity and sedentary behaviors in relation to the risk for gestational diabetes mellitus," Archives of Internal Medicine, vol. 166, no. 5, pp. 543-548, 2006.

[45] H. S. Ros, S. Cnattingius, and L. Lipworth, "Comparison of risk factors for preeclampsia and gestational hypertension in a population-based cohort study," American Journal of Epidemiology, vol. 147, no. 11, pp. 1062-1070, 1998.

[46] N. J. Sebire, M. Jolly, J. P. Harris, et al., "Maternal obesity and pregnancy outcome: a study of 287213 pregnancies in London," International Journal of Obesity and Related Metabolic Disorders, vol. 25, no. 8, pp. 1175-1182, 2001.

[47] T. E. O'Brien, J. G. Ray, and W. S. Chan, "Maternal body mass index and the risk of preeclampsia: a systematic overview," Epidemiology, vol. 14, no. 3, pp. 368-374, 2003.

[48] M. I. Cedergren, "Maternal morbid obesity and the risk of adverse pregnancy outcome," Obstetrics \& Gynecology, vol. 103, no. 2, pp. 219-224, 2004.

[49] L. M. Bodnar, J. M. Catov, M. A. Klebanoff, R. B. Ness, and J. M. Roberts, "Prepregnancy body mass index and the occurrence of severe hypertensive disorders of pregnancy," Epidemiology, vol. 18, no. 2, pp. 234-239, 2007.

[50] J. G. Ray, M. J. Vermeulen, M. J. Schull, S. McDonald, and D. A. Redelmeier, "Metabolic syndrome and the risk of placental dysfunction," Journal of Obstetrics and Gynaecology Canada, vol. 27, no. 12, pp. 1095-1101, 2005.

[51] M. Wolf, L. Sandler, K. Muñoz, K. Hsu, J. L. Ecker, and R. Thadhani, "First trimester insulin resistance and subsequent preeclampsia: a prospective study," Journal of Clinical Endocrinology \& Metabolism, vol. 87, no. 4, pp. 1563-1568, 2002.

[52] L. M. Bodnar, G. Tang, R. B. Ness, G. Harger, and J. M. Roberts, "Periconceptional multivitamin use reduces the risk of preeclampsia," American Journal of Epidemiology, vol. 164, no. 5 , pp. 470-477, 2006.
[53] I. Delbaere, H. Verstraelen, S. Goetgeluk, G. Martens, G. De Backer, and M. Temmerman, "Pregnancy outcome in primiparae of advanced maternal age," European Journal of Obstetrics Gynecology \& Reproductive Biology, vol. 135, no. 1, pp. 41-46, 2007.

[54] S. C. Kalhan, "Protein metabolism in pregnancy," American Journal of Clinical Nutrition, vol. 71, no. 5, supplement, pp. 1249S-1255S, 2000.

[55] E. Sivan and G. Boden, "Free fatty acids, insulin resistance, and pregnancy," Current Diabetes Reports, vol. 3, no. 4, pp. 319-322, 2003.

[56] J. M. Potter and P. J. Nestel, "The hyperlipidemia of pregnancy in normal and complicated pregnancies," American Journal of Obstetrics \& Gynecology, vol. 133, no. 2, pp. 165170, 1979.

[57] J. Bonnar, L. Daly, and B. L. Sheppard, "Changes in the fibrinolytic system during pregnancy," Seminars in Thrombosis and Hemostasis, vol. 16, no. 3, pp. 221-229, 1990.

[58] D. M. Sherer and O. Abulafia, "Angiogenesis during implantation, and placental and early embryonic development," Placenta, vol. 22, no. 1, pp. 1-13, 2001.

[59] B. Sibai, G. Dekker, and M. Kupferminc, "Pre-eclampsia," The Lancet, vol. 365, no. 9461, pp. 785-799, 2005.

[60] J. M. Roberts and C. W. G. Redman, "Pre-eclampsia: more than pregnancy-induced hypertension," The Lancet, vol. 341, no. 8858, pp. 1447-1451, 1993.

[61] G. T. R. Manten, M. J. Sikkema, H. A. M. Voorbij, G. H. A. Visser, H. W. Bruinse, and A. Franx, "Risk factors for cardiovascular disease in women with a history of pregnancy complicated by preeclampsia or intrauterine growth restriction," Hypertension in Pregnancy, vol. 26, no. 1, pp. 39-50, 2007.

[62] V. A. Rodie, D. J. Freeman, N. Sattar, and I. A. Greer, "Preeclampsia and cardiovascular disease: metabolic syndrome of pregnancy?" Atherosclerosis, vol. 175, no. 2, pp. 189-202, 2004.

[63] J. Newstead, P. von Dadelszen, and L. A. Magee, "Preeclampsia and future cardiovascular risk," Expert Review of Cardiovascular Therapy, vol. 5, no. 2, pp. 283-294, 2007.

[64] R. J. Kaaja and I. A. Greer, "Manifestations of chronic disease during pregnancy," Journal of the American Medical Association, vol. 294, no. 21, pp. 2751-2757, 2005.

[65] I. A. Brosens, P. De Sutter, T. Hamerlynck, et al., "Endometriosis is associated with a decreased risk of preeclampsia," Human Reproduction, vol. 22, no. 6, pp. 17251729, 2007.

[66] F. Xue and K. B. Michels, "Intrauterine factors and risk of breast cancer: a systematic review and meta-analysis of current evidence," Lancet Oncology, vol. 8, no. 12, pp. 10881100, 2007.

[67] J. Vamecq and N. Latruffe, "Medical significance of peroxisome proliferator-activated receptors," The Lancet, vol. 354, no. 9173, pp. 141-148, 1999.

[68] J. M. Lehmann, L. B. Moore, T. A. Smith-Oliver, W. O. Wilkison, T. M. Willson, and S. A. Kliewer, "An antidiabetic thiazolidinedione is a high affinity ligand for peroxisome proliferator-activated receptor $\gamma$ (PPAR $\gamma$ )," Journal of Biological Chemistry, vol. 270, no. 22, pp. 12953-12956, 1995.

[69] H. Vosper, G. A. Khoudoli, T. L. Graham, and C. N. Palmer, "Peroxisome proliferator-activated receptor agonists, hyperlipidaemia, and atherosclerosis," Pharmacology \& Therapeutics, vol. 95, no. 1, pp. 47-62, 2002.

[70] C. Chambrier, J.-P. Bastard, J. Rieusset, et al., "Eicosapentaenoic acid induces mRNA expression of peroxisome 
proliferator-activated receptor $\gamma$," Obesity Research, vol. 10, no. 6, pp. 518-525, 2002.

[71] S. A. Kliewer, J. M. Lenhard, T. M. Willson, I. Patel, D. C. Morris, and J. M. Lehmann, "A prostaglandin $\mathrm{J}_{2}$ metabolite binds peroxisome proliferator-activated receptor $\gamma$ and promotes adipocyte differentiation," Cell, vol. 83, no. 5, pp. 813819, 1995.

[72] G. Chinetti, J.-C. Fruchart, and B. Staels, "Peroxisome proliferator-activated receptors (PPARs): nuclear receptors at the crossroads between lipid metabolism and inflammation," Inflammation Research, vol. 49, no. 10, pp. 497-505, 2000.

[73] L. Waite, E. C. Person, Y. Zhou, K.-H. Lim, T. S. Scanlan, and R. N. Taylor, "Placental peroxisome proliferator-activated receptor- $\gamma$ is up-regulated by pregnancy serum," Journal of Clinical Endocrinology \& Metabolism, vol. 85, no. 10, pp. 3808-3814, 2000.

[74] Q. Wang, H. Fujii, and G. T. Knipp, "Expression of PPAR and RXR isoforms in the developing rat and human term placentas," Placenta, vol. 23, no. 8-9, pp. 661-671, 2002.

[75] A. Tarrade, R. Lai Kuen, A. Malassiné, et al., "Characterization of human villous and extravillous trophoblasts isolated from first trimester placenta," Laboratory Investigation, vol. 81, no. 9, pp. 1199-1211, 2001.

[76] A. Yessoufou, A. Hichami, P. Besnard, K. Moutairou, and N. A. Khan, "Peroxisome proliferator-activated receptor $\alpha$ deficiency increases the risk of maternal abortion and neonatal mortality in murine pregnancy with or without diabetes mellitus: modulation of T cell differentiation," Endocrinology, vol. 147, no. 9, pp. 4410-4418, 2006.

[77] Y. Barak, D. Liao, W. He, et al., "Effects of peroxisome proliferator-activated receptor $\delta$ on placentation, adiposity, and colorectal cancer," Proceedings of the National Academy of Sciences of the United States of America, vol. 99, no. 1, pp. 303-308, 2002.

[78] T. Fournier, L. Pavan, A. Tarrade, et al., "The role of PPAR$\gamma / \mathrm{RXR}-\alpha$ heterodimers in the regulation of human trophoblast invasion," Annals of the New York Academy of Sciences, vol. 973, pp. 26-30, 2002.

[79] Y.-J. Zhu, S. E. Crawford, V. Stellmach, et al., "Coactivator PRIP, the peroxisome proliferator-activated receptorinteracting protein, is a modulator of placental, cardiac, hepatic, and embryonic development," Journal of Biological Chemistry, vol. 278, no. 3, pp. 1986-1990, 2003.

[80] P. Antonson, G. U. Schuster, L. Wang, et al., "Inactivation of the nuclear receptor coactivator RAP250 in mice results in placental vascular dysfunction," Molecular and Cellular Biology, vol. 23, no. 4, pp. 1260-1268, 2003.

[81] V. Sapin, P. Dollé, C. Hindelang, P. Kastner, and P. Chambon, "Defects of the chorioallantoic placenta in mouse RXR $\alpha$ null fetuses," Developmental Biology, vol. 191, no. 1, pp. 29-41, 1997.

[82] N. Kubota, Y. Terauchi, H. Miki, et al., "PPAR $y$ mediates high-fat diet-induced adipocyte hypertrophy and insulin resistance," Molecular Cell, vol. 4, no. 4, pp. 597-609, 1999.

[83] O. Wendling, P. Chambon, and M. Mark, "Retinoid X receptors are essential for early mouse development and placentogenesis," Proceedings of the National Academy of Sciences of the United States of America, vol. 96, no. 2, pp. 547-551, 1999.

[84] L. L. H. Peeters, J.-L. Vigne, M. K. Tee, D. Zhao, L. Waite, and R. N. Taylor, "PPAR $\gamma$ represses VEGF expression in human endometrial cells: implications for uterine angiogenesis," Angiogenesis, vol. 8, no. 4, pp. 373-379, 2006.
[85] H. Bamba, S. Ota, A. Kato, C. Kawamoto, and K. Fujiwara, "Prostaglandins up-regulate vascular endothelial growth factor production through distinct pathways in differentiated U937 cells," Biochemical and Biophysical Research Communications, vol. 273, no. 2, pp. 485-491, 2000.

[86] V. Chintalgattu, G. S. Harris, S. M. Akula, and L. C. Katwa, "PPAR- $\gamma$ agonists induce the expression of VEGF and its receptors in cultured cardiac myofibroblasts," Cardiovascular Research, vol. 74, no. 1, pp. 140-150, 2007.

[87] K. Yamakawa, M. Hosoi, H. Koyama, et al., "Peroxisome proliferator-activated receptor- $\gamma$ agonists increase vascular endothelial growth factor expression in human vascular smooth muscle cells," Biochemical and Biophysical Research Communications, vol. 271, no. 3, pp. 571-574, 2000.

[88] T. Shalom-Barak, J. M. Nicholas, Y. Wang, et al., "Peroxisome proliferator-activated receptor $\gamma$ controls Mucl transcription in trophoblasts," Molecular and Cellular Biology, vol. 24, no. 24, pp. 10661-10669, 2004.

[89] A. Tarrade, K. Schoonjans, J. Guibourdenche, et al., "PPAR $\gamma / \operatorname{RXR} \alpha$ heterodimers are involved in human CG $\beta$ synthesis and human trophoblast differentiation," Endocrinology, vol. 142, no. 10, pp. 4504-4514, 2001.

[90] W. T. Schaiff, I. Bildirici, M. Cheong, P. L. Chern, D. M. Nelson, and Y. Sadovsky, "Peroxisome proliferator-activated receptor- $\gamma$ and retinoid $\mathrm{X}$ receptor signaling regulate fatty acid uptake by primary human placental Trophoblasts," Journal of Clinical Endocrinology \& Metabolism, vol. 90, no. 7, pp. 4267-4275, 2005.

[91] M. Lappas, M. Permezel, and G. E. Rice, "Leptin and adiponectin stimulate the release of proinflammatory cytokines and prostaglandins from human placenta and maternal adipose tissue via nuclear factor- $\kappa \mathrm{B}$, peroxisomal proliferator-activated receptor- $\gamma$ and extracellularly regulated kinase 1/2," Endocrinology, vol. 146, no. 8, pp. 33343342, 2005.

[92] K. Handschuh, J. Guibourdenche, M. Guesnon, I. Laurendeau, D. Evain-Brion, and T. Fournier, "Modulation of PAPPA expression by PPAR $\gamma$ in human first trimester trophoblast," Placenta, vol. 27, supplement 1, pp. 127-134, 2006.

[93] R. L. Schild, W. T. Schaiff, M. G. Carlson, E. J. Cronbach, D. M. Nelson, and Y. Sadovsky, "The activity of PPAR $y$ in primary human trophoblasts is enhanced by oxidized lipids," Journal of Clinical Endocrinology \& Metabolism, vol. 87, no. 3, pp. 1105-1110, 2002.

[94] R. Asami-Miyagishi, S. Iseki, M. Usui, K. Uchida, H. Kubo, and I. Morita, "Expression and function of PPAR $y$ in rat placental development," Biochemical and Biophysical Research Communications, vol. 315, no. 2, pp. 497-501, 2004.

[95] E. Capobianco, A. Jawerbaum, M. C. Romanini, et al., "15deoxy- $\Delta^{12,14}$-prostaglandin $\mathrm{J}_{2}$ and peroxisome proliferatoractivated receptor $\gamma(\operatorname{PPAR} \gamma)$ levels in term placental tissues from control and diabetic rats: modulatory effects of a PPAR $\gamma$ agonist on nitridergic and lipid placental metabolism," Reproduction, Fertility and Development, vol. 17, no. 4, pp. 423433, 2005.

[96] M. Lappas, M. Permezel, H. M. Georgiou, and G. E. Rice, "Regulation of proinflammatory cytokines in human gestational tissues by peroxisome proliferator-activated receptor$\gamma$ : effect of 15-deoxy- $\Delta^{12,14}-\mathrm{PGJ}_{2}$ and troglitazone," Journal of Clinical Endocrinology \& Metabolism, vol. 87, no. 10, pp. 4667-4672, 2002.

[97] K. W. Marvin, R. L. Eykholt, J. A. Keelan, T. A. Sato, and M. D. Mitchell, "The 15-deoxy- $\Delta^{12,14}$-prostaglandin $\mathrm{J}_{2}$ receptor, 
peroxisome proliferator activated receptor- $\gamma(\operatorname{PPAR} \gamma)$ is expressed in human gestational tissues and is functionally active in JEG3 choriocarcinoma cells," Placenta, vol. 21, no. 4, pp. 436-440, 2000.

[98] L. R. Dunn-Albanese, W. E. Ackerman IV, Y. Xie, J. D. Iams, and D. A. Kniss, "Reciprocal expression of peroxisome proliferator-activated receptor- $\gamma$ and cyclooxygenase- 2 in human term parturition," American Journal of Obstetrics \& Gynecology, vol. 190, no. 3, pp. 809-816, 2004.

[99] E. B. E. Berry, R. Eykholt, R. J. A. Helliwell, R. S. Gilmour, M. D. Mitchell, and K. W. Marvin, "Peroxisome proliferatoractivated receptor isoform expression changes in human gestational tissues with labor at term," Molecular Pharmacology, vol. 64, no. 6, pp. 1586-1590, 2003.

[100] B. M. Forman, P. Tontonoz, J. Chen, R. P. Brun, B. M. Spiegelman, and R. M. Evans, " 15 -deoxy- $\Delta^{12,14}$-prostaglandin $\mathrm{J}_{2}$ is a ligand for the adipocyte determination factor PPAR $\gamma$," Cell, vol. 83, no. 5, pp. 803-812, 1995.

[101] R. L. Schild, C. M. Sonnenberg-Hirche, W. T. Schaiff, I. Bildirici, D. M. Nelson, and Y. Sadovsky, "The kinase p38 regulates peroxisome proliferator activated receptor- in human trophoblasts," Placenta, vol. 27, no. 2-3, pp. 191-199, 2006.

[102] S. S.-T. Lee and F. J. Gonzalez, "Targeted disruption of the peroxisome proliferator-activated receptor $\alpha$ gene, PPAR $\alpha$," Annals of the New York Academy of Sciences, vol. 804, no. 1, pp. 524-529, 1996.

[103] G. B. Dealtry, M. K. O'Farrell, and N. Fernandez, “The Th2 cytokine environment of the placenta," International Archives of Allergy and Immunology, vol. 123, no. 2, pp. 107-119, 2000.

[104] J. C. Huang, W. S. Wun, J. S. Goldsby, I. C. Wun, D. Noorhasan, and K. K. Wu, "Stimulation of embryo hatching and implantation by prostacyclin and peroxisome proliferator-activated receptor $\delta$ activation: implication in IVF," Human Reproduction, vol. 22, no. 3, pp. 807-814, 2007.

[105] H. Lim and S. K. Dey, "PPAR $\delta$ functions as a prostacyclin receptor in blastocyst implantation," Trends in Endocrinology \& Metabolism, vol. 11, no. 4, pp. 137-142, 2000.

[106] M. Lappas, M. Permezel, H. M. Georgiou, and G. E. Rice, "Nuclear factor $\kappa$ B regulation of proinflammatory cytokines in human gestational tissues in vitro," Biology of Reproduction, vol. 67, no. 2, pp. 668-673, 2002.

[107] S. A. Törnblom, F. A. Patel, B. Byström, et al., "15Hydroxyprostaglandin dehydrogenase and cyclooxygenase 2 messenger ribonucleic acid expression and immunohistochemical localization in human cervical tissue during term and preterm labor," Journal of Clinical Endocrinology \& Metabolism, vol. 89, no. 6, pp. 2909-2915, 2004.

[108] M. Lappas, M. Permezel, and G. E. Rice, "15-deoxy- $\Delta^{12,14}$ rostaglandin $\mathrm{J}_{2}$ and troglitazone regulation of the release of phospholipid metabolites, inflammatory cytokines and proteases from guman gestational tissues," Placenta, vol. 27, no. 11-12, pp. 1060-1072, 2006.

[109] E. T. McKinney, R. Shouri, R. S. Hunt, R. A. Ahokas, and B. M. Sibai, "Plasma, urinary, and salivary 8 -epi-prostaglandin $\mathrm{F}_{2 \alpha}$ levels in normotensive and preeclamptic pregnancies," American Journal of Obstetrics \& Gynecology, vol. 183, no. 4, pp. 874-877, 2000.

[110] D. B. Klinkner, H. J. Lim, E. Y. Strawn Jr., K. T. Oldham, and T. L. Sander, "An in vivo murine model of rosiglitazone use in pregnancy," Fertility and Sterility, vol. 86, no. 4, supplement 1, pp. 1074-1079, 2006.

[111] L. Waite, R. E. Louie, and R. N. Taylor, "Circulating activators of peroxisome proliferator-activated receptors are reduced in preeclamptic pregnancy," Journal of Clinical Endocrinology \& Metabolism, vol. 90, no. 2, pp. 620-626, 2005.

[112] E. C. Tok, D. Ertunc, O. Bilgin, E. M. Erdal, M. Kaplanoglu, and S. Dilek, "PPAR- $\gamma 2$ Pro12Ala polymorphism is associated with weight gain in women with gestational diabetes mellitus," European Journal of Obstetrics Gynecology \& Reproductive Biology, vol. 129, no. 1, pp. 25-30, 2006.

[113] A. Jawerbaum, E. Capobianco, C. Pustovrh, et al., "Influence of peroxisome proliferator-activated receptor $\gamma$ activation by its endogenous ligand 15 -deoxy $\Delta^{12,14}$ prostaglandin $\mathrm{J}_{2}$ on nitric oxide production in term placental tissues from diabetic women," Molecular Human Reproduction, vol. 10, no. 9, pp. 671-676, 2004.

[114] L. Capparuccia, D. Marzioni, A. Giordano, et al., "PPAR $y$ expression in normal human placenta, hydatidiform mole and choriocarcinoma," Molecular Human Reproduction, vol. 8, no. 6, pp. 574-579, 2002.

[115] V. A. Rodie, A. Young, F. Jordan, N. Sattar, I. A. Greer, and D. J. Freeman, "Human placental peroxisome proliferatoractivated receptor $\delta$ and $\gamma$ expression in healthy pregnancy and in preeclampsia and intrauterine growth restriction," Journal of the Society for Gynecologic Investigation, vol. 12, no. 5, pp. 320-329, 2005.

[116] A. Meirhaeghe, C. A. G. Boreham, L. J. Murray, et al., "A possible role for the PPARG Pro12Ala polymorphism in preterm birth," Diabetes, vol. 56, no. 2, pp. 494-498, 2007.

[117] J. R. Higgins and M. de Swiet, "Blood-pressure measurement and classification in pregnancy," The Lancet, vol. 357, no. 9250, pp. 131-135, 2001.

[118] A. P. Mackay, C. J. Berg, and H. K. Atrash, "Pregnancy-related mortality from preeclampsia and eclampsia," Obstetrics \& Gynecology, vol. 97, no. 4, pp. 533-538, 2001.

[119] R. N. Taylor, C. J. M. de Groot, Y. K. Cho, and K.-H. Lim, "Circulating factors as markers and mediators of endothelial cell dysfunction in preeclampsia," Seminars in Reproductive Endocrinology, vol. 16, no. 1, pp. 17-31, 1998.

[120] Y. Hamai, T. Fujii, T. Yamashita, et al., "Evidence for an elevation in serum interleukin-2 and tumor necrosis factor- $\alpha$ levels before the clinical manifestations of preeclampsia," American Journal of Reproductive Immunology, vol. 38, no. 2, pp. 89-93, 1997.

[121] K.-A. Wathén, E. Tuutti, U.-H. Stenman, et al., "Maternal serum-soluble vascular endothelial growth factor receptor1 in early pregnancy ending in preeclampsia or intrauterine growth retardation," Journal of Clinical Endocrinology \& Metabolism, vol. 91, no. 1, pp. 180-184, 2006.

[122] S.-M. Yie, L.-H. Li, Y.-M. Li, and C. Librach, "HLA-G protein concentrations in maternal serum and placental tissue are decreased in preeclampsia," American Journal of Obstetrics \& Gynecology, vol. 191, no. 2, pp. 525-529, 2004.

[123] R. Thadhani, W. P. Mutter, M. Wolf, et al., "First trimester placental growth factor and soluble FMS-like tyrosine kinase 1 and risk for preeclampsia," Journal of Clinical Endocrinology \& Metabolism, vol. 89, no. 2, pp. 770-775, 2004.

[124] D. V. Coonrod, D. E. Hickok, K. Zu, T. R. Easterling, and J. R. Daling, "Risk factors for preeclampsia in twin pregnancies: a population-based cohort study," Obstetrics \& Gynecology, vol. 85, no. 5, part 1, pp. 645-650, 1995.

[125] M. J. McMahon, C. V. Ananth, and R. M. Liston, "Gestational diabetes mellitus: risk factors, obstetric complications and infant outcomes," Journal of Reproductive Medicine for the Obstetrician and Gynecologist, vol. 43, no. 4, pp. 372-378, 1998. 
[126] M. Tanaka, G. Jaamaa, M. Kaiser, et al., "Racial disparity in hypertensive disorders of pregnancy in New York state: a 10year longitudinal population-based study," American Journal of Public Health, vol. 97, no. 1, pp. 163-170, 2007.

[127] B. A. Beamer, C.-J. Yen, R. E. Andersen, et al., "Association of the Pro12Ala variant in the peroxisome proliferator- activated receptor- $\gamma 2$ gene with obesity in two Caucasian populations," Diabetes, vol. 47, no. 11, pp. 1806-1808, 1998.

[128] S. J. Hasstedt, Q.-F. Ren, K. Teng, and S. C. Elbein, "Effect of the peroxisome proliferator-activated receptor- $\gamma 2$ Pro12Ala variant on obesity, glucose homeostasis, and blood pressure in members of familial type 2 diabetic kindreds," Journal of Clinical Endocrinology \& Metabolism, vol. 86, no. 2, pp. 536$541,2001$.

[129] W.-D. Li, J. H. Lee, and R. A. Price, "The peroxisome proliferator-activated receptor $\gamma 2$ Pro12Ala mutation is associated with early onset extreme obesity and reduced fasting glucose," Molecular Genetics and Metabolism, vol. 70, no. 2, pp. 159-161, 2000.

[130] S. S. Deeb, L. Fajas, M. Nemoto, et al., "A Pro12Ala substitution in PPAR $\gamma 2$ associated with decreased receptor activity, lower body mass index and improved insulin sensitivity," $\mathrm{Na}$ ture Genetics, vol. 20, no. 3, pp. 284-287, 1998.

[131] J. Laasanen, S. Heinonen, M. Hiltunen, A. Mannermaa, and M. Laakso, "Polymorphism in the peroxisome proliferatoractivated receptor- $\gamma$ gene in women with preeclampsia," Early Human Development, vol. 69, no. 1-2, pp. 77-82, 2002.

[132] C. A. Hubel, "Oxidative stress in the pathogenesis of preeclampsia," Proceedings of the Society for Experimental Biology and Medicine, vol. 222, no. 3, pp. 222-235, 1999.

[133] B. W. Arbogast, S. C. Leeper, R. D. Merrick, K. E. Olive, and R. N. Taylor, "Which plasma factors bring about disturbance of endothelial function in pre-eclampsia?" The Lancet, vol. 343, no. 8893, pp. 340-341, 1994.

[134] C. W. G. Redman and I. L. Sargent, "Pre-eclampsia, the placenta and the maternal systemic inflammatory response-a review," Placenta, vol. 24, supplement 1, pp. S21-S27, 2003.

[135] M. J. Reginato, S. L. Krakow, S. T. Bailey, and M. A. Lazar, "Prostaglandins promote and block adipogenesis through opposing effects on peroxisome proliferator-activated receptor $\gamma$," Journal of Biological Chemistry, vol. 273, no. 4, pp. 1855-1858, 1998.

[136] P. L. Ogburn Jr., S. B. Johnson, P. P. Williams, and R. T. Holman, "Levels of free fatty acids and arachidonic acid in pregnancy and labor," Journal of Laboratory and Clinical Medicine, vol. 95, no. 6, pp. 943-949, 1980.

[137] P. L. Ogburn Jr., P. P. Williams, S. B. Johnson, and R. T. Holman, "Serum arachidonic acid levels in normal and preeclamptic pregnancies," American Journal of Obstetrics \& Gynecology, vol. 148, no. 1, pp. 5-9, 1984.

[138] C. J. M. de Groot, J. T. Murai, J.-L. Vigne, and R. N. Taylor, "Eicosanoid secretion by human endothelial cells exposed to normal pregnancy and preeclampsia plasma in vitro," Prostaglandins Leukotrienes and Essential Fatty Acids, vol. 58, no. 2, pp. 91-97, 1998.

[139] D. Hornung, I. P. Ryan, V. A. Chao, J.-L. Vigne, E. D. Schriock, and R. N. Taylor, "Immunolocalization and regulation of the chemokine RANTES in human endometrial and endometriosis tissues and cells," Journal of Clinical Endocrinology \& Metabolism, vol. 82, no. 5, pp. 1621-1628, 1997.

[140] S. Blackburn and D. Loper, Maternal Fetal and Neonatal Physiology: A Clinical Perspective, Harcourt Brace Jovanovic, Philadelphia, Pa, USA, 1992.
[141] W. W. Hay Jr., "Placental transport of nutrients to the fetus," Hormone Research, vol. 42, no. 4-5, pp. 215-222, 1994.

[142] L. Jovanovic and D. J. Pettitt, "Gestational diabetes mellitus," Journal of the American Medical Association, vol. 286, no. 20, pp. 2516-2518, 2001.

[143] C. B. Rudra, T. K. Sorensen, W. M. Leisenring, E. Dashow, and M. A. Williams, "Weight characteristics and height in relation to risk of gestational diabetes mellitus," American Journal of Epidemiology, vol. 165, no. 3, pp. 302-308, 2007.

[144] F. Galtier-Dereure, C. Boegner, and J. Bringer, "Obesity and pregnancy: complications and cost," American Journal of Clinical Nutrition, vol. 71, no. 5, supplement, pp. 1242S1248S, 2000.

[145] P. M. Catalano, "Increasing maternal obesity and weight gain during pregnancy: the obstetric problems of plentitude," $\mathrm{Ob}$ stetrics \& Gynecology, vol. 110, no. 4, pp. 743-744, 2007.

[146] C. J. P. Jones and H. Fox, "Placental changes in gestational diabetes. An ultrastructural study," Obstetrics \& Gynecology, vol. 48, no. 3, pp. 274-280, 1976.

[147] A. Åberg, H. Rydhstroem, and A. Frid, "Impaired glucose tolerance associated with adverse pregnancy outcome: a population-based study in southern Sweden," American Journal of Obstetrics \& Gynecology, vol. 184, no. 2, pp. 77-83, 2001.

[148] D. B. Carr, K. M. Utzschneider, R. L. Hull, et al., "Gestational diabetes mellitus increases the risk of cardiovascular disease in women with a family history of type 2 diabetes," Diabetes Care, vol. 29, no. 9, pp. 2078-2083, 2006.

[149] H. Lee, H. C. Jang, H. K. Park, and N. H. Cho, "Early manifestation of cardiovascular disease risk factors in offspring of mothers with previous history of gestational diabetes mellitus," Diabetes Research and Clinical Practice, vol. 78, no. 2, pp. 238-245, 2007.

[150] M. Morifuji, C. Sanbongi, and K. Sugiura, "Dietary soya protein intake and exercise training have an additive effect on skeletal muscle fatty acid oxidation enzyme activities and mRNA levels in rats," British Journal of Nutrition, vol. 96, no. 3, pp. 469-475, 2006.

[151] C. Zhang, S. Liu, C. G. Solomon, and F. B. Hu, "Dietary fiber intake, dietary glycemic load, and the risk for gestational diabetes mellitus," Diabetes Care, vol. 29, no. 10, pp. 2223-2230, 2006.

[152] E. Oken, Y. Ning, S. L. Rifas-Shiman, J. S. Radesky, J. W. RichEdwards, and M. W. Gillman, "Associations of physical activity and inactivity before and during pregnancy with glucose tolerance," Obstetrics \& Gynecology, vol. 108, no. 5, pp. 12001207, 2006.

[153] T. L. Weissgerber, L. A. Wolfe, G. A. L. Davies, and M. F. Mottola, "Exercise in the prevention and treatment of maternalfetal disease: a review of the literature," Applied Physiology, Nutrition and Metabolism, vol. 31, no. 6, pp. 661-674, 2006.

[154] H. Leipold, M. Knoefler, C. Gruber, A. Huber, P. Haslinger, and C. Worda, "Peroxisome proliferator-activated receptor $\gamma$ coactivator- $1 \alpha$ gene variations are not associated with gestational diabetes mellitus," Journal of the Society for Gynecologic Investigation, vol. 13, no. 2, pp. 104-107, 2006.

[155] S. Fukuen, M. Iwaki, A. Yasui, M. Makishima, M. Matsuda, and I. Shimomura, "Sulfonylurea agents exhibit peroxisome proliferator-activated receptor $\gamma$ agonistic activity," Journal of Biological Chemistry, vol. 280, no. 25, pp. 23653-23659, 2005.

[156] O. Langer, D. L. Conway, M. D. Berkus, E. M.-J. Xenakis, and O. Gonzales, "A comparison of glyburide and insulin in women with gestational diabetes mellitus," New England Journal of Medicine, vol. 343, no. 16, pp. 1134-1138, 2000. 
[157] C. Ferretti, L. Bruni, V. Dangles-Marie, A. P. Pecking, and D. Bellet, "Molecular circuits shared by placental and cancer cells, and their implications in the proliferative, invasive and migratory capacities of trophoblasts," Human Reproduction Update, vol. 13, no. 2, pp. 121-141, 2007.

[158] D. P. Hewitt, P. J. Mark, and B. J. Waddell, "Placental expression of peroxisome proliferator-activated receptors in rat pregnancy and the effect of increased glucocorticoid exposure," Biology of Reproduction, vol. 74, no. 1, pp. 23-28, 2006.

[159] W. T. Schaiff, F. F. Knapp Jr., Y. Barak, T. Biron-Shental, D. M. Nelson, and Y. Sadovsky, "Ligand-activated peroxisome proliferator activated receptor $\gamma$ alters placental morphology and placental fatty acid uptake in mice," Endocrinology, vol. 148, no. 8, pp. 3625-3634, 2007.

[160] J. A. Keelan, R. J. A. Helliwell, B. E. Nijmeijer, et al., "15deoxy- $\Delta^{12,14}$-prostaglandin $\mathrm{J}_{2}$-induced apoptosis in amnionlike WISH cells," Prostaglandins \& Other Lipid Mediators, vol. 66, no. 4, pp. 265-282, 2001.

[161] H. Hasegawa, H. Takano, Y. Zou, et al., "Pioglitazone, a peroxisome proliferator-activated receptor $\gamma$ activator, ameliorates experimental autoimmune myocarditis by modulating Th1/Th2 balance," Journal of Molecular and Cellular Cardiology, vol. 38, no. 2, pp. 257-265, 2005.

[162] S. Dasgupta, A. Roy, M. Jana, D. M. Hartley, and K. Pahan, "Gemfibrozil ameliorates relapsing-remitting experimental autoimmune encephalomyelitis independent of peroxisome proliferator-activated receptor- $\alpha$," Molecular Pharmacology, vol. 72, no. 4, pp. 934-946, 2007. 


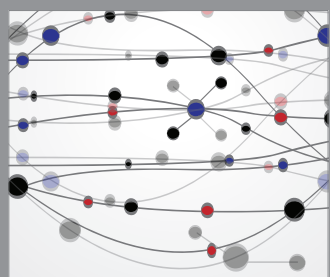

The Scientific World Journal
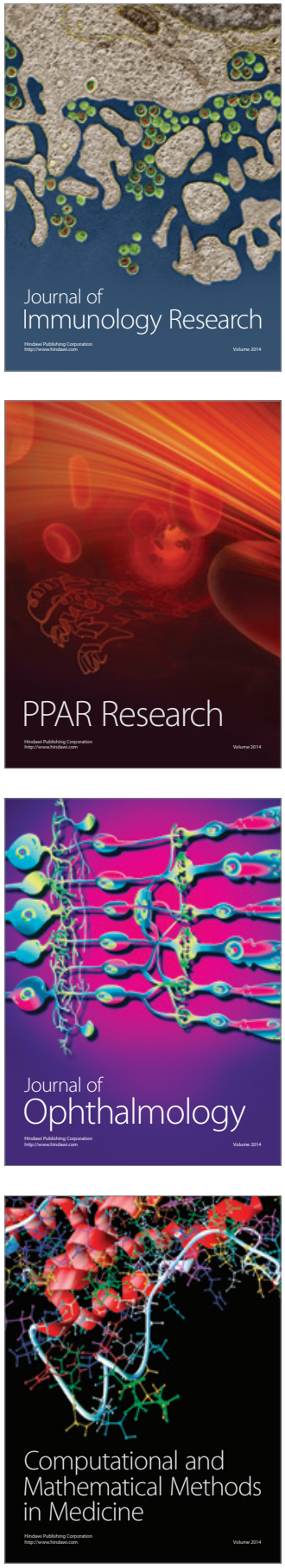

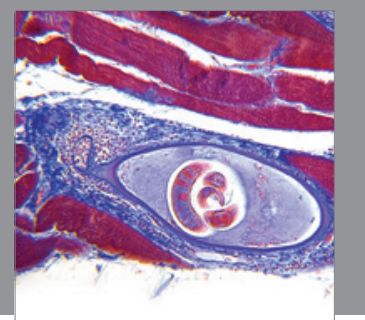

Gastroenterology

Research and Practice
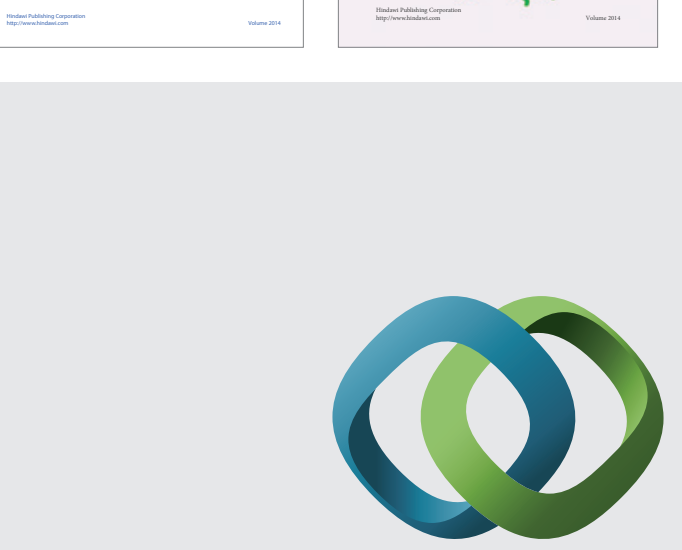

\section{Hindawi}

Submit your manuscripts at

http://www.hindawi.com
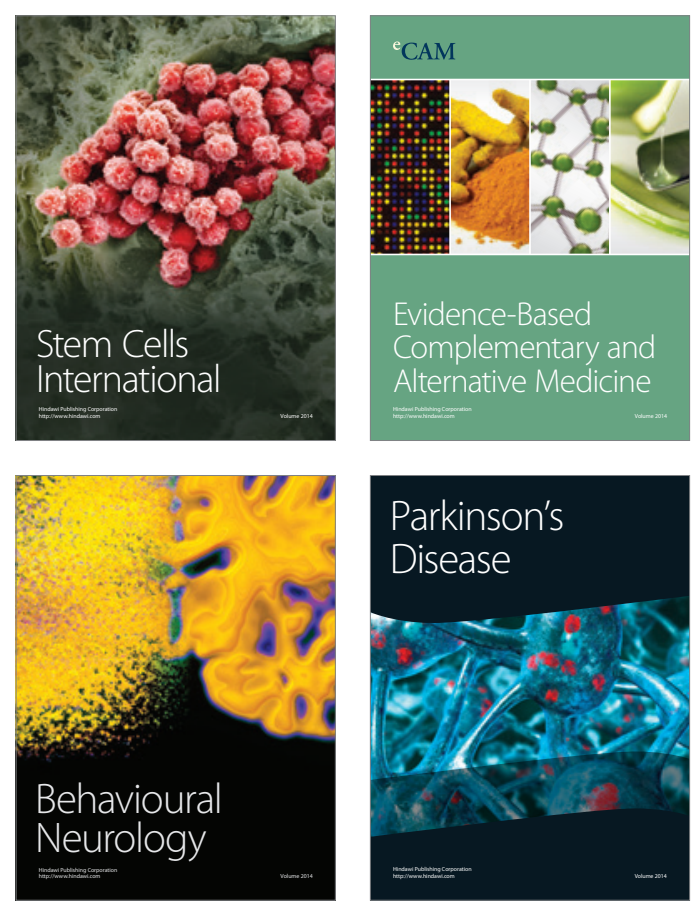

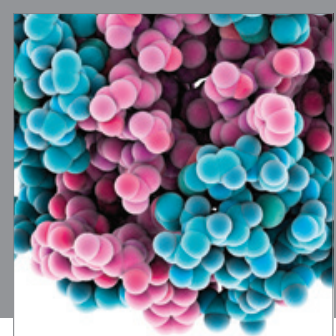

Journal of
Diabetes Research

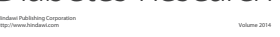

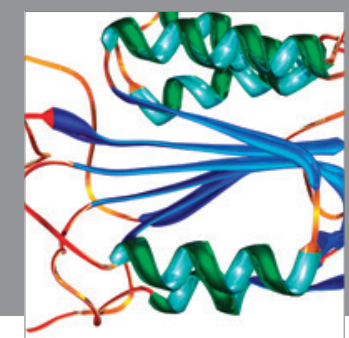

Disease Markers
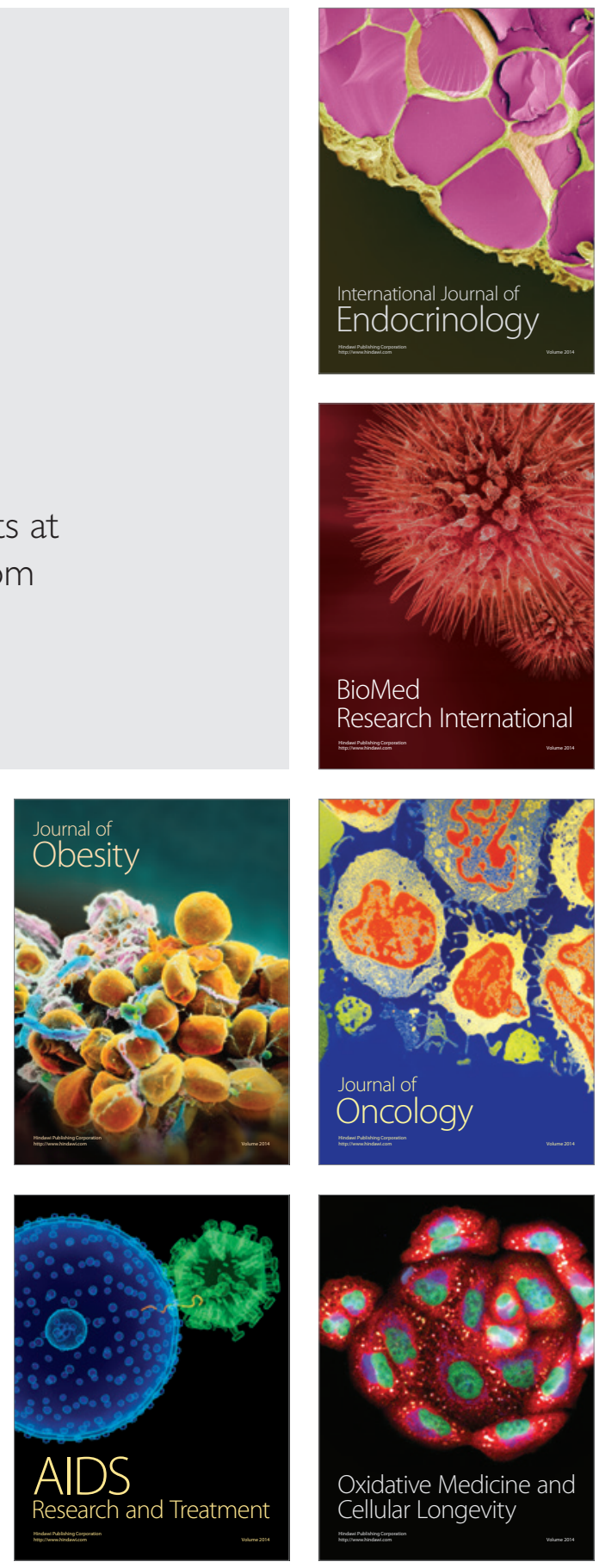